of all these reactions is that substitution occurs with major products being the meta-isomers. This is in complete contradiction in all cases to liquid-phase halogenations where ortho/para substitution predominates.

Kooyman said that a radical mechanism ulone could not readily explain the specificity of the results obtained and put forward the novel suggestion that the reactions occurred through an ionic intermediate, that is :

$$
\begin{aligned}
X_{2} & \rightarrow 2 X \\
X+\mathrm{ArH} & \rightarrow[\mathrm{ArH}+]\left[X^{-}\right]
\end{aligned}
$$

A proton is then lost from the position with highest positive charge, that is, the meta position :

$$
\begin{gathered}
{\left[\mathrm{ArH}^{+}\right]\left[X^{-}\right] \rightarrow \mathrm{Ar}+\mathrm{H} X} \\
\mathrm{Ar}+X_{2} \rightarrow \operatorname{Ar} X+X
\end{gathered}
$$

This mechanism provoked a lively discussion, and the outcome of Prof. Kooyman's present work on the kinetics of these reactions is awaited with interest.
Finally, Dr. B. A. Thrush (Cambridge) described spectroscopic studies of bromine atom recombination. The studies employed the technique of flash photolysis to study the recombination of bromine atoms in ixcess argon to determine whether the bromine molecules formed in the recombination are produced in an electronically excited state or with excess vibrational energy. No evidence for the former was found but absorption spectra obtained during the recombination showed an appreciable increase in the population of the lower excited vibrational levels of the ground-state, notably $v^{\prime \prime}=1,2,3,4$ and 5 .

The distribution of this energy corresponded to temperatures much higher than those to be expected from the amount of energy absorbed from the flash.

The papers presented stimulated a lively discussion throughout and thus ensured the success of the meeting.

\section{J. H. Thомas}

E. WhitrLe

\title{
AUTHOR AND PUBLISHER
}

$\mathrm{P}^{\mathrm{H}}$ OBLEMS arising in connexion with the publication of scientific books were discussed at a recent meeting of the Scientific Publications Council held at the Ciba Foundation, London. Prof. G. W. Harris was in the chair.

Mr. David Dickens (Pitman Medical Publishing Co.) said that the publication of scientific books is not a lucrative business. Seientifie books are generally written for the specialist, and consequently the market for them is small. A publisher of scientific text-books must maintain a staff of highly qualified editors and sub-editors, generally with science degrees, who work together with the authors to get the manuscripts into shape for publication. This is often a long process involving heavy investment: one book alone might cost $\mathfrak{f 4 , 5 0 0}$ to produce and may take many years to bring back the outlay. The publisher contributes, as indicated by his 'imprint', prestige, knowledge of the field and 'know-how'. $\mathrm{He}$ has the same interest as the author in getting a book published as quickly as he can.

\section{Ownership of Copyright}

$\mathrm{Mr}_{\mathrm{r}}$. Dickens stated that the copyright is the author's as soon as he puts pen to paper. The publisher is generally better able to deal with selling the rights than the author, and he should do this in the author's name. Difficulties may arise if a book is written by joint authors who later decide to part. Mr. D. M. Neale (Oxford University Press) believed that it is often more convenient for the publisher to hold the copyright in order to protect the author's interests, although this is not necessarily a good general rule. His firm has been taking legal action to stop a book being pirated in Hong Kong: it could not have done this if the copyright were in the author's name, since the author was in Europe doing research. The cost of fighting an action of this kind is enormous and is all borne by the firm. When an institute publishes a series of volumes, the copyright is sometimes held by the institute: otherwise the Oxford University Press prefers to keep the copyright and return to the author whatever they may get from sale of the rights. Difficulties can arise if a publisher holding the copyright is taken over by another firm: the author has generally no defence against that. Miss M. E. Barber (Society of Authors) said that some publishers never take the copyright, but others do claim it, often in the first clause of the contract. The copyright includes translation, broadcasting, television, film, drama, digests and paperback editions. The Society of Authors takes the view that the publisher does not need the copyright: he should negotiate the rights as the author's agent. Scientists often regard writing as a side-line, and they do not take the trouble they should over contracts: publishers therefore treat scientists in a way in which they would not treat other authors. Only if piracy were rife enough to be an overriding consideration would it be justified for the publisher to hold the copyright.

Mr. A. L. Bacharach (Nutrition Society) said that the author of a paper in a scientific journal is in a different position from the same author when writing a text-book. The copyright of a scientific paper is owned by the author, unless he has specifically assigned it to a body, such as a learned society: but recently it has been suggested that the copyright of a paper belongs to the employer of the author. Dr. E. A. Moelwyn-Hughes (Cambridge) said that some countries still take no notice of copyright. When in the U.S.S.R. he had discovered by chance that 20,000 copies of a book by him had been distributed there, but he had received no royalties from the Russians. He had heard that there was also a Japanese edition, from which he also had no royalties. It is generally understood that an author can quote material from another publication so long as he gives the source and reference, but some publishers object to this. What is the legal position? Miss Barber replied that quoting from another publication is often done by scientists, but it is an infringement of copyright to quote "a substantial part" of a copyright work without permission. Even summarizing a publication of another author or publishing an abstract is an infringement of copyright if done without permission. 


\section{Contractual Relationships}

Prof. G. V. R. Born (London) said he knew of scientists who had experienced difficulties with their publishers. How can scientists be warned about publishing difficulties? Contracts often contain an arbitration clause which may delay decision in disputes; would it be better for authors if there was no such clause? Can a publisher be asked for an audited account? Miss Barber said that an author is entitled to detailed royalty statements and that, if he had good reason to doubt their accuracy, he had a common law right to inspect the publishers' books of account, though this was a little cumbersome to enforce. The name of an unreliable firm cannot be published openly or broadcast; but a name can be omitted from a list of recommended firms. Mr. Bacharach said that the good publisher presents no difficulty: contracts are necessary, because there are bad publishers who try to manipulate an agreement to the author's disadvantage. Sometimes contracts contain a clause giving the publisher the right to call on the author to prepare a new edition; they should include also a clause requiring the publisher to let the author make such revisions as he may wish to a new issue. This is particularly desirable in scientific broadeasting; the B.B.C. has agreed that there should be no repeat after six months without giving the author a chance to revise.

Dr. Moelwyn-Hughes referred to an eminent scientist who had been cheated by a publisher. Something needs to be done in the scientific world to combat the recent development of mushroom firms that are financially slick and trade on the business incompetence of the scientist. Dr. D. Richter (Carshalton) said that British publishers have built up a high reputation in the past, so that authors have come to trust their publishers as they would their doctors or solicitors, but recently publishers of a different type, interested mainly in quick profits, have entered the scientific field. There have been instances when the publisher has sold rights without informing the author, when inaccurate royalty statements have been given and when scientists have received no royalties at all from sales of their books. Unfortunately the reliable old-established firms tend to be slow and do not always appreciate the special requirements of the scientist. The mushroom firms are exploiting the good faith of the scientific writer and giving British publishers a bad name. Prof. G. W. Harris said there is a need especially for the younger scientists to be informed of the situation.

D. Richter

\section{SOUTH-EASTERN UNION OF SCIENTIFIC SOCIETIES ANNUAL CONGRESS}

\begin{abstract}
A $\mathrm{T}$ the invitation of the Haslemere Natural History Society and the management committee of the Educational Museum, the South-eastern Union of Seientific Societies held its sixty-sixth annual congress at Haslemere during May 26-28, under the presidency of Prof. S. W. Wooldridge. The Council's choice of the theme for the congress of "The Changing Countryside" proved successful, allowing the lecturers full freedom in the presentation of their subjects and of focusing attention on the need for preservation and the desirability of intelligent management in Nature conservation. The delegates were welcomed by Dr. Rolston, chairman of the management committee of the Museum.

The young naturalists' evening included a brains trust with questions answered by a panel of experts, under the chairmanship of Maxwell Knight, followed by the screening of a film "Journey into Spring", introductory to the visit to Selborne.

The presidential address was given by Prof. S. W. Wooldridge, whose subject was "The Land and Man in the Western Weald". He commenced by emphasiz. ing that, although the land existed before man, it was not an environment until man entered on it and reacted to it. The notion that the Weald is a denuded simple anticline has existed for some 150 years, from the time of John Fairey, who also introduced the use of the term 'denudation'. His observations of the area were made from the top of a stage-coach in the days of leisurely travel. It is now known that between the south coast and the Thames valley there are six anticlinal crests, somewhat resembling corrugated iron in form. For convenience of understanding, Prof. Wooldridge defined the country west of Stane Street as the Western Weald, wherein the Hythe Beds suddenly expand to form a major feature. It was
\end{abstract}

important to remember that at one time the Chalk stood 2,000-2,500 ft. above the present land-level near Haslemere. Dealing with the influence on subsoil and soil types, it was pointed out that the intermediate and loamy soils are not derived from one particular formation, but have different soil parents. Our ancestors chose the Upper Greensand at the base of the chalk as good growing land, the best arable ground. It should be remembered that the dry valleys were not dry even in Romano-British times. Prof. Wooldridge next dealt with the succession of occupants. During Mesolithic times, about 6,000 B.c., when the climate was wetter than at present, the area on the Surrey-Sussex border was occupied. Evidence of man's later activities, during Neolithic times, had been found in the ditches at the Trundles. The following early Bronze Age had the same type of life and culture, and it was not until the late Bronze Age that the real cultivation of the land began. There is evidence of industry and trade during the Iron Age, 500 B.o.; the so-called hill forts are really the beginnings of cities on the hills. A later stage was the creation of the village communi. ties, about A.D. 600, located by the early Saxon placenames, often those of pagan deities. The last stage is indicated by the distribution of the Domesday vils, the parish boundaries showing a remarkably even pattern, especially along the edge of the Tertiary beds.

The zoological section was addressed by John Sankey, on "Invertebrate Life in South-east England". He has for 14 years been fighting a campaign for greater investigation of the lesser-known invertebrate animals. The butterflies and beetles had been studied well enough, but such groups as centipedes and spiders need far more attention, especially observational work on their life-history and ecology. 